\title{
Treatment Processes of Leachate from a Landfill by Advanced Oxidation Fenton and Ozone-UV
}

\author{
Díaz Rodea Sebastián1, Solís Correa Hugo Eduardo¹, Gómez Salazar Sergio², \\ Giacomán Vallejos Germán ${ }^{3}$, Méndez Novelo Roger Iván³, \\ Barceló Quintal Icela Dagmar ${ }^{* *}$ (1)
}

${ }^{1}$ Department of Basic Sciences, Autonomous Metropolitan University, Azcapotzalco, Mexico City, Mexico ${ }^{2}$ Department of Chemical Engineering, University Center for Exact Sciences and Engineering, University of Guadalajara, Guadalajara, Jalisco, México

${ }^{3}$ Faculty of Engineering, Autonomous University of Yucatán, Mérida, Yucatán, Mexico

Email: ^ibarceloq@gmail.com

How to cite this paper: Sebastián, D.R., Eduardo, S.C.H., Sergio, G.S., Germán, G.V., Iván, M.N.R. and Dagmar, B.Q.I. (2021) Treatment Processes of Leachate from a Landfill by Advanced Oxidation Fenton and Ozone-UV. Journal of Environmental Protection, 12, 755-766.

https://doi.org/10.4236/jep.2021.1210045

Received: September 5, 2021

Accepted: October 23, 2021

Published: October 26, 2021

Copyright $\odot 2021$ by author(s) and Scientific Research Publishing Inc. This work is licensed under the Creative Commons Attribution International License (CC BY 4.0).

http://creativecommons.org/licenses/by/4.0/

(c) (i) Open Access

\begin{abstract}
In this paper it is presented the results of advanced oxidation of leachates from a technified sanitary landfill located in the State of Querétaro, Mexico. One characteristic of already stabilized leachates from sanitary landfills like this case, is their difficult degradation, mainly because the organic matter contained is recalcitrant. For the samples collect, four sites were selected, where three points per site were sampled, measuring at each site the parameters: temperature, $\mathrm{pH}$, conductivity, redox potential (ORP) and dissolved oxygen (DO) and leachate samples were collected. On the other hand, the Chemical Oxygen Demand (COD) of crude leachates, leachates acidified and leachates oxidized by Fenton reagent and Ozone-UV combined were analyzed. COD was used to monitor the degradation kinetics. With the results, the ArcGIS software was applied to study the distribution of temperature, dissolved oxygen and COD mainly in the leachate lagoon. For the application of Fenton reagent in the crude leachate oxidation, the $\mathrm{pH}$ was first adjusted and $\mathrm{Fe}^{2+} / \mathrm{H}_{2} \mathrm{O}_{2}$ ratio was optimized. The efficiency of Ozone-UV treatments was studied through COD degradation kinetics. The graphs of in $(\mathrm{Ci} / \mathrm{Co})$ vs time, showed that the kinetic processes are of order one, with very acceptable regression coefficients $\left(\mathrm{R}^{2}\right)$ and extraordinarily similar speed constants (K). With Fenton oxidation, the highest percentage of COD degradation was achieved and with Ozone-UV oxidation, it was possible to practically degrade all the COD.
\end{abstract}

\section{Keywords}

Landfill, Leachate, Fenton Oxidation, Ozone-UV Oxidation, Degradation 


\section{Introduction}

In the construction of technical sanitary landfills, the land is selected with certain characteristics that allow to control the liquids (leachates) produced through oxidation ponds. A leachate is defined as a liquid that is formed by the reaction, dragging or filtering of the materials that constitute the waste and that contain in dissolved and suspended substances with high toxicity (SEMARNAT, 2003). The final disposal of Urban Solid Waste (MSW) has evolved from open-air landfills to highly technical landfills, where liquid (leachate) and potentially dangerous gaseous emissions for the environment are controlled in the latter. In both openair landfills and early sanitary landfills, leachates had no control and these leached into surface water sources or infiltrated the soils, contaminating the aquifers underlying them. [1] [2]. The authors [3] [4] and [5] have considered that the phases in the decomposition of MSW in sanitary landfills are related to the age of the leachates. The author [6] made a classification of leachates based on their characteristics of $\mathrm{pH}, \mathrm{COD}, \mathrm{TOC}, \mathrm{BOD}_{5}$ and volatile fatty acids (VFA) and its age, in young (less than 5 years), medium (5 to 10 years) and old or stabilized (older than 10 years). The authors [6] and [7], studied and obtained leachate results, where the organic content was dependent on the class of decomposition conditions, the acetic acid and volatile fatty acids produced in the leachate in his study showed high values of $\mathrm{COD}$ and $\mathrm{BOD}_{5}$. In the next degradation stage, these acids were converted to $\mathrm{CO}_{2}$ and $\mathrm{CH}_{4}$, so the organic content of the leachate decreased notably. Due to the content of leachates as organic components, their toxicity, its corrosiveness and their difficult degradation, it is important to establish some treatments for this type of substances that is easy to apply and, to a certain extent, economical. The difficult degradation, especially of stabilized leachates, can be through combined advanced oxidation treatments, such as the Fenton reaction as the first step, where a good number of organic components would be degraded, and to complete degradation it is possible to use an additional oxidation combining ozone with UV irradiation, since the problem of leachate lagoons in Mexico is that leachates of all ages are mixed.

The oxidation by the Fenton reagent has been shown to be effective in the treatment of leachates [6] [8] [9] [10] and [11], in which the pollutant load is treated with a combination of $\mathrm{Fe}^{2+}$ and $\mathrm{H}_{2} \mathrm{O}_{2}$. This oxidation consists of a homogeneous catalytic system in which an iron salt, which can be $\mathrm{FeSO}_{4}$ or $\mathrm{FeCl}_{2}$, generates $\mathrm{HO}$ - radicals by the interaction of hydrogen peroxide $\left(\mathrm{H}_{2} \mathrm{O}_{2}\right)$ with $\mathrm{Fe}^{2+}$. Author [12], proposed the following reactions:

$$
\begin{gathered}
\mathrm{Fe}^{2+}+\mathrm{H}_{2} \mathrm{O}_{2} \rightarrow \mathrm{Fe}^{3+}+\mathrm{HO} \bullet+\mathrm{HO}^{-} \\
\mathrm{Fe}^{3+}+\mathrm{H}_{2} \mathrm{O}_{2} \rightarrow \mathrm{Fe}^{2+}+\mathrm{HOO} \bullet+\mathrm{H}^{+} \\
\mathrm{Fe}^{2+}+\mathrm{HO} \bullet \rightarrow \mathrm{Fe}^{3+}+\mathrm{HO}^{-}
\end{gathered}
$$




$$
\begin{gathered}
\mathrm{HO} \bullet+\mathrm{H}_{2} \mathrm{O}_{2} \rightarrow \mathrm{HOO} \bullet+\mathrm{H}_{2} \mathrm{O} \\
\mathrm{Fe}^{2+}+\mathrm{HOO} \bullet+\mathrm{H}^{+} \rightarrow \mathrm{Fe}^{3+}+\mathrm{H}_{2} \mathrm{O}_{2} \\
\mathrm{Fe}^{3+}+\mathrm{HOO} \bullet \rightarrow \mathrm{Fe}^{2+}+\mathrm{H}^{+}+\mathrm{O}_{2} \\
\mathrm{Fe}^{2+}+\mathrm{HOO} \bullet \rightarrow \mathrm{Fe}^{3+}+\mathrm{HOO}^{-}
\end{gathered}
$$

The range of applicability of the technique is also limited by the $\mathrm{pH}$ of the medium. The optimum $\mathrm{pH}$ for the reaction is between 3 and 6 . With the Fenton oxidation, the degrees of reduction of the COD have reached up to $97 \%$ with respect to the initial values [13].

Regarding the treatment with ozone, its oxidizing power is strong, where its efficiency also depends on the $\mathrm{pH}$, the presence of free radicals such as $\mathrm{OH} \bullet$ and HOO• are active in the oxidation of pollutants. The following potentials illustrate the differences between the oxidative properties of ozone and oxygen [6] and [14]:

$$
\begin{array}{ll}
\mathrm{O}_{2}+4 \mathrm{H}^{+}+4 \mathrm{e}^{-} \rightleftarrows 2 \mathrm{H}_{2} \mathrm{O} & \mathrm{E}^{\mathrm{o}}=+1.229 \mathrm{~V} \\
\mathrm{O}_{2}+2 \mathrm{H}_{2} \mathrm{O}+4 \mathrm{e}^{-} \rightleftarrows \mathrm{HO}^{-} & \mathrm{E}^{\mathrm{o}}=+0.401 \mathrm{~V} \\
\mathrm{O}_{2}+4 \mathrm{H}^{+}(\mathrm{pH}=7)+4 \mathrm{e}^{-} \rightleftarrows 2 \mathrm{H}_{2} \mathrm{O} & \mathrm{E}^{\mathrm{o}}=+0.815 \mathrm{~V} \\
\mathrm{O}_{3}+2 \mathrm{H}^{+}+2 \mathrm{e}^{-} \rightleftarrows \mathrm{H}_{2} \mathrm{O}+\mathrm{O}_{2} & \mathrm{E}^{\mathrm{o}}=+2.071 \mathrm{~V} \\
\mathrm{O}_{3}+\mathrm{H}_{2} \mathrm{O}+2 \mathrm{e}^{-} \rightleftarrows \mathrm{O}_{2}+2 \mathrm{HO}^{-} & \mathrm{E}^{\mathrm{o}}=+1.220 \mathrm{~V} \\
\mathrm{O}_{3}+2 \mathrm{H}^{+}(\mathrm{pH}=7)+2 \mathrm{e}^{-} \rightleftarrows \mathrm{H}_{2} \mathrm{O}+\mathrm{O}_{2} & \mathrm{E}^{\mathrm{o}}=+1.650 \mathrm{~V}
\end{array}
$$

On the other hand, UV light is used in leachates treatment [15] is efficient in the presence of $\mathrm{H}_{2} \mathrm{O}_{2}$, according to [16] and [17], it is based on the formation of hydroxyl radicals $(\mathrm{OH} \bullet)$ from the photolysis of hydrogen peroxide and the formation of radicals takes place due to the incident photons absorbed using lamps with an emission range between 180 and $400 \mathrm{~nm}$, or more specific monochromatic $(254 \mathrm{~nm})$ to obtain a higher performance in the photolysis of peroxide. The main reactions of the oxidation mechanism by UV radiation are the following:

Initiation:

$$
\begin{aligned}
& \mathrm{H}_{2} \mathrm{O}_{2}+h v \rightarrow 2 \mathrm{OH} \bullet \\
& \mathrm{H}_{2} \mathrm{O}_{2} \rightarrow \mathrm{H}_{2} \mathrm{O}+\frac{1}{2} \mathrm{O}_{2}
\end{aligned}
$$

Propagation:

$$
\begin{gathered}
\mathrm{OH} \bullet+\mathrm{H}_{2} \mathrm{O}_{2} \rightarrow \mathrm{HO}_{2} \bullet+\mathrm{H}_{2} \mathrm{O} \\
\mathrm{HO}_{2} \bullet+\mathrm{H}_{2} \mathrm{O}_{2} \rightarrow \mathrm{OH} \bullet+\mathrm{H}_{2} \mathrm{O}+\mathrm{O}_{2} \\
\mathrm{HO}_{2} \bullet+\mathrm{HO}_{2} \bullet \rightarrow \mathrm{OH} \bullet+\mathrm{OH}^{-}+\mathrm{O}_{2}
\end{gathered}
$$

Termination:

$$
\begin{gathered}
\mathrm{OH} \bullet+\mathrm{HO}_{2} \bullet \rightarrow \mathrm{H}_{2} \mathrm{O}+\mathrm{O}_{2} \\
\mathrm{OH} \bullet+\mathrm{OH} \bullet \rightarrow \mathrm{H}_{2} \mathrm{O}_{2}
\end{gathered}
$$


The objective of this work is to present the results of a set of leachate treatments from the sanitary landfill of an Ecological Center for Integral Waste Management in the State of Querétaro (CEMIRQ, Mexico, through advanced oxidation by Fenton and subsequent treatment combined with ozone and UV.

\section{Experimental Methodology}

\subsection{Sampling Site Location}

The sample collection site was in a leachate lagoon of the sanitary landfill of the Ecological Center of Integral Waste Management Querétaro (CEMIRQ), in Querétaro State, Mexico. This is located near a cliff that blocks sunlight completely at two sites in the leachate lagoon, partially at one site and during the morning at another, Figure 1. The sampling was carried out considering the Mexico Standard [18] collecting three samples for each site as indicated in Figure 1. Each site was named: Site 1, Site 2, Site 3 and Site 4, a van Dorn equipment was used for sampling at $1.50 \mathrm{~m}$ depth; the lagoon has an average depth of 2.5 meters. These samples were stored at $4^{\circ} \mathrm{C}$. The lagoon has a very dark color, Figure 1.

\subsection{Determination of Physicochemical and Chemical Parameters}

\subsubsection{In Situ Parameters}

The temperature, $\mathrm{pH}$ and conductivity were measured with a LabQuest-Vernier interface field equipment manufacturer's manual was considered for each case and the analysis were based on the Mexican standards [19] [20] and [21] respectively. Regarding the redox potential (ORP), a LabQuest-Vernier equipment and its respective electrode were also used, using the [22] ASTM technique, (1996). These parameters were measured three times for each of the three points at each site.

\subsubsection{Analysis of Chemical Oxygen Demand (COD)}

Organic matter was measured as COD. For analysis, the samples were oxidized in a HANNA Instruments HI839800 reactor, based on Standard Methods [23], It was subsequently measured in a DR/2400 $\mathrm{HACH}$ spectrophotometer, according to [23].

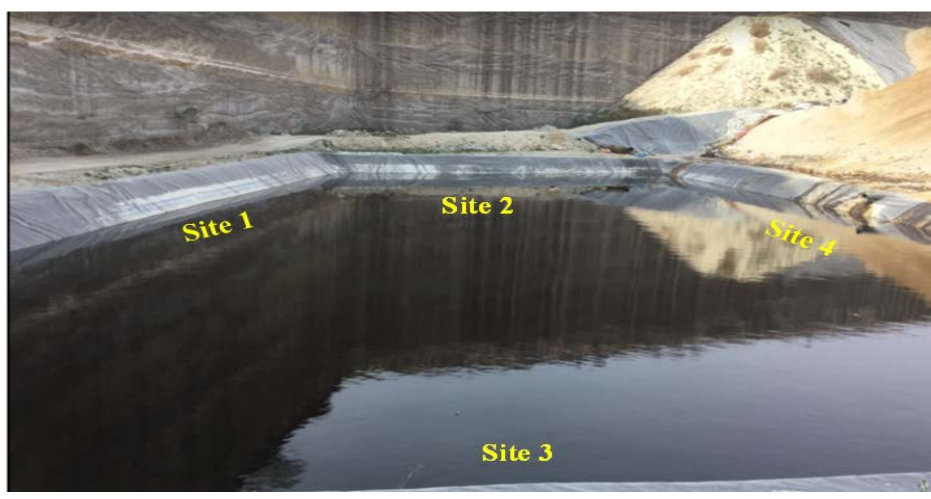

Figure 1. Sampling sites, three sampling points per site were considered. 


\subsubsection{Adjusting the $\mathrm{pH}$, Optimization $\mathrm{Fe} / \mathrm{H}_{2} \mathrm{O}_{2}$ Ratio and Fenton Oxidation}

First the pH was adjusted between $3-5$ with $\mathrm{H}_{2} \mathrm{SO}_{4}$ concentrated (J.T. Baker, 95.0\% - 8.0\%), this is really important for the correct addition of $\mathrm{Fe}^{2+}$ and $\mathrm{H}_{2} \mathrm{O}_{2}$. $5.11 \mathrm{~g}$ of the iron salt $\left(\mathrm{FeSO}_{4} 7 \mathrm{H}_{2} \mathrm{O}\right.$, J.T. Baker $\left.99.0 \%-104.5 \%\right)$ were added and the $\mathrm{H}_{2} \mathrm{O}_{2}$ (J.T. Baker $30.0 \%-32.0 \%$ ) was slowly added until completing $15 \mathrm{~mL}$ to have the $\mathrm{Fe}^{2+} / \mathrm{H}_{2} \mathrm{O}_{2}$ ratio of 0.125 (previously optimized, following the [24] methodology, at a speed of $1 \mathrm{~mL}$ every minute, for one correct Fenton reaction treatment. The COD was utilized as a monitoring parameter.

\subsubsection{Combined Ozone-UV Oxidation}

The combined treatment with ozone and UV was carried out, after the Fenton oxidation with Batch technique. The parameter for ozonation and UV monitoring was also COD, this was monitored at different times: $(0.20,40,60,80,100$, $120,140,160,180 \mathrm{~min})$. The ozone was produced in a specifically built O3Residual brand generator, see Figure 2(a). The ozone generator's duty cycle was established at 0.4 liters of oxygen per minute and an operating voltage of $7 \mathrm{kVolts}$. The ozonation reaction was carried out in a $31 \times 3.8 \mathrm{~cm}$ quartz reactor with $34 / 45$ standard mouth, for 8 hours, a pH range between 7 and 8. A Cole Parmer model lamp was used for UV radiation with high density ultraviolet light and long wavelength of $365 \mathrm{~mm}$, intensity of 21,000 micro-W/CM2 at 2" and 8900 micro-W/CM A 10" that operates at 115 volts and $60 \mathrm{hz}$. In Figure 2(b), the complete $\mathrm{O}_{3}$-UV system is presented. All measurements and analysis of the different parameters were carried out in triplicate.

The leachate lagoon was mapped using ArcGIS software for the distribution of temperature, dissolved $\mathrm{O}_{2}$ and COD at the four sites selected. The IDW and Arc Map interpolators were used to prepare the maps.

\section{Results and Discussion}

The results of this work are presented below.

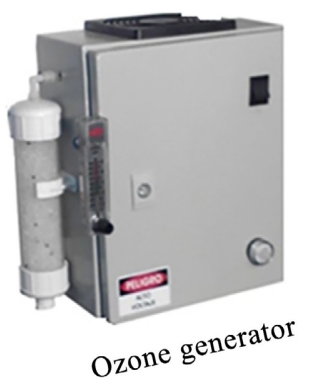

(a)

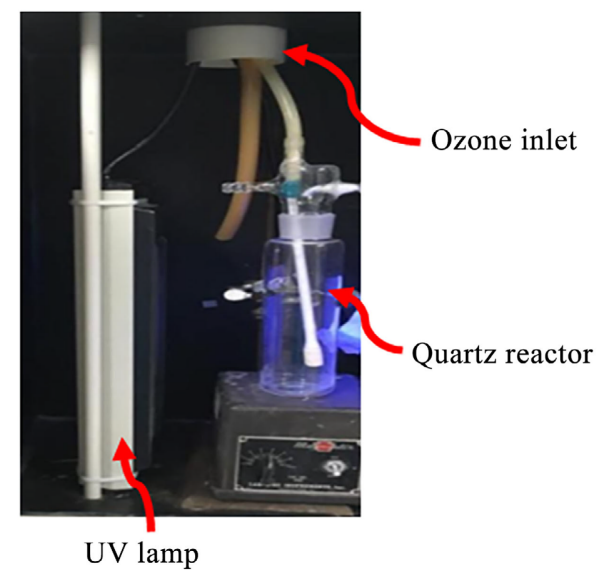

(b)

Figure 2. (a) Ozone generator. (b) Ozone-UV combined system. 


\subsection{Temperature}

By analyzing the temperature, the highest values were obtained at the Sites 3 and 4 , which are the sites that receive some sun and the lowest values were Site 2 and Site 1 that practically do not receive sun, due to a very high cliff that prevents the arrival of sunlight, Figure 1. In Figure 3, according to the ArcGIS software, it is shown how the temperature is distributed in the leachate lagoon, where the pink color presents the highest temperature values and the green color the lowest. It is noted that the temperature is not homogeneous in all lagoon, site 3 receives the most sunlight and sites 1 and 2 is the coldest.

\section{2. $\mathrm{pH}$ of Leachates}

The $\mathrm{pH}$ values were between 8.61 and 8.52 , these values indicate that the leachate from the lagoon is stabilized. According to [7] and [24], those leachates with a $\mathrm{pH}$ greater than 8 are stabilized, have a low biodegradability $\mathrm{BOD}_{5} / \mathrm{COD}$ $=0.1, \mathrm{TOC} / \mathrm{COD}=0.4$, indicating the presence of difficult oxidation compounds with weights greater than $5000 \mathrm{~g} / \mathrm{mol}$ [6] and [25]. The $\mathrm{pH}$ is important in the composition of a leachate, because it depends on the concentrations of acids present and $\mathrm{CO}_{2}$ that comes from the landfill. Rainfall and the waste type, are the most important factors affecting the composition of the leachate [26]. Table 1 indicates the $\mathrm{pH}$ distribution in leachate lagoon, the Site 4 presented a somewhat higher $\mathrm{pH}$, with respect to the other sites. These values are important, since all the leachate show stability, indicating the presence of compounds that are difficult to oxidize.

\subsubsection{Conductivity}

Table 1 shows the conductivity values, which were high, indicate the presence of high concentrations of dissolved ions. The magnitude of the $\mathrm{pH}$ suggests the presence of bicarbonates; by the smell and the almost zero OD concentration suggest that sulfides predominate.

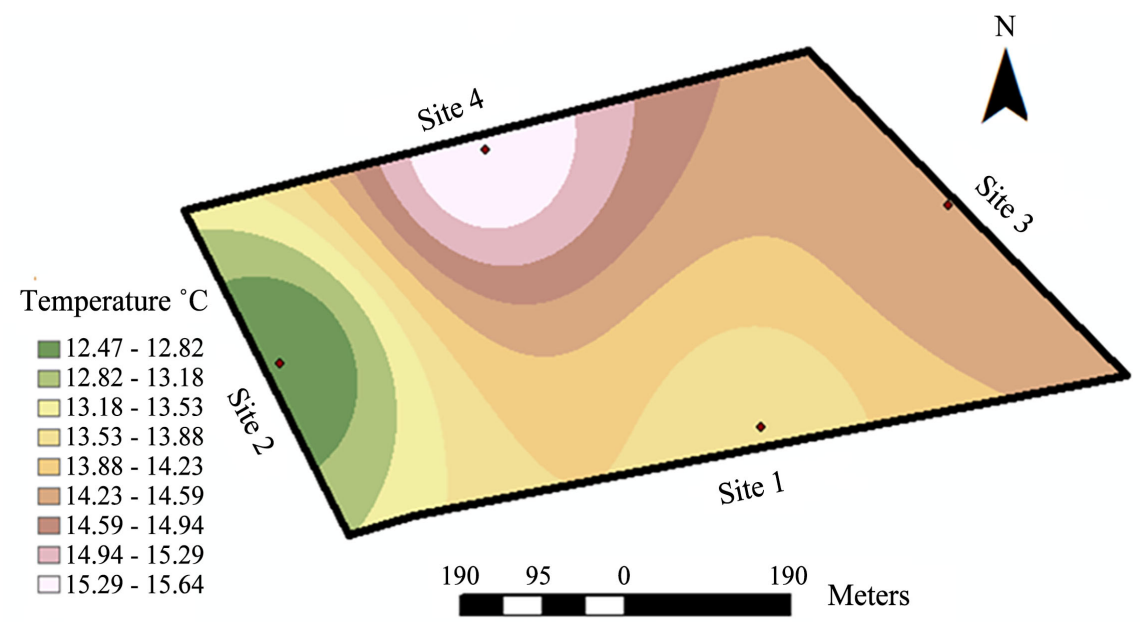

Figure 3. Temperature distribution according to ArcGIS software in the leachate lagoon. 
Table 1. Values of the parameters measured in situ in the leachate lagoon.

\begin{tabular}{cccc}
\hline Sites & Hydrogen potential $(\mathrm{pH})$ & Conductivity $(\mu \mathrm{S} / \mathrm{cm})$ & Redox potential, ORP, $(\mathrm{mV})$ \\
\hline Site 1 & $8.51 \pm 0.035$ & $34,400.00 \pm 547.723$ & $-194.40 \pm 4.624$ \\
Site 2 & $8.55 \pm 0.015$ & $33,522.67 \pm 517.178$ & $-197.78 \pm 3.677$ \\
Site 3 & $8.55 \pm 0.015$ & $40,977.00 \pm 112.892$ & $-203.96 \pm 6.484$ \\
Site 4 & $8.59 \pm 0.010$ & $39,485.33 \pm 264.652$ & $-203.67 \pm 4.426$ \\
\hline
\end{tabular}

\subsubsection{Redox Potential (ORP)}

This parameter is closely related to DO. At the four sites very negative values were presented, which means very low oxygen concentration. This can be seen in Table 1. The sites that presented lowest negative values were Sites 3 and 4. This is consistent with temperature and solar incidence, since Site 4 receives most of the light.

\subsection{Dissolved Oxygen (D0)}

Figure 4 shows the Dissolved Oxygen (DO) distribution map, which together with the ORP are important parameters due to their relationship with COD. The importance of this parameter lies in that it indicates the degree of oxygenation of the leachate lagoon, which presents anoxia due to the very low concentration of DO at each site. These low values coincide with the negative values of the ORP. Since these leachates are already stabilized (this is presented by their dark color), it is logical that the DO concentration is very low, it can be seen in Figure 2 that Site 4 shows a higher value, possibly due to the wind that allows a little dissolution of oxygen or perhaps the rain, although this oxygen is quickly used in the degradation of carbonaceous material. When analyzing the sites, it is observed that the leachate lagoon is acting as a practically anaerobic system.

\subsection{COD from Crude Leachate}

The most important parameter for leachate treatment is COD, Figure 5 shows the distribution of COD in the leachate lagoon. Differences in COD values may be due to: the design of the sanitary landfill, the composition of the MSW, the characteristics of the site and the age of the sanitary landfill [6] and [7]. If the distribution map is analyzed, the COD presents an inverse panorama to that of DO since it is a parameter related to the amount of oxygen consumed by the oxidizable material in the lagoon, whatever its origin, organic or inorganic. COD, together with DO, are related to ORP (see Table 1 for negative values).

For COD, its concentration in the crude leachate was first determined. Table 2 shows the concentrations at each site, considering the analysis of the samples for every three points per site. Figure 5 shows the distribution of COD in the leachate lagoon. Site 1 was the one with the highest concentration compared to the other sites, (green color). In general, the average crude leachate was around $14,940 \pm 85,987$. As indicated in the previous parameters, the COD was not homogeneous throughout the lagoon, Sites 3 and 4 presented less concentration which is also related to temperature, mainly where there is some solar radiation, 
therefore, the process of oxidation of organic matter and the performance of anaerobic bacteria is greater.

\subsection{COD from Leachate with Adjusted pH}

To carry out the oxidation with the Fenton reagent, it was necessary to adjust the $\mathrm{pH}$ of each leachate to a value of $3 \pm 0.144$, for which a volume of $0.009 \pm$ $0.00045 \mathrm{~mL}$ of $\mathrm{H}_{2} \mathrm{SO}_{4}$ (concentrate) was used for each $\mathrm{mL}$ of crude leachate. Table 2 shows the COD concentrations in $\mathrm{mg} / \mathrm{L}$, resulting after acidification. At this stage, when concentrated sulfuric acid was used, there was a small oxidation due to the presence of $\mathrm{SO}_{3}$, which is an oxide that works as a strong oxidant with

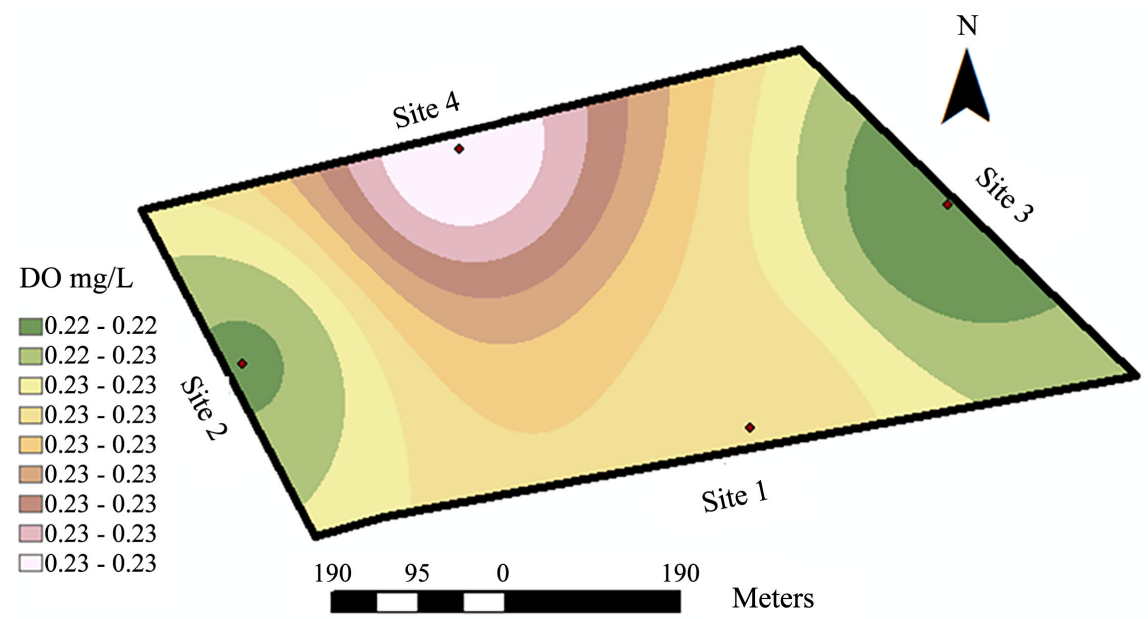

Figure 4. Oxygen dissolved distribution according to ArcGIS software in the leachate lagoon.

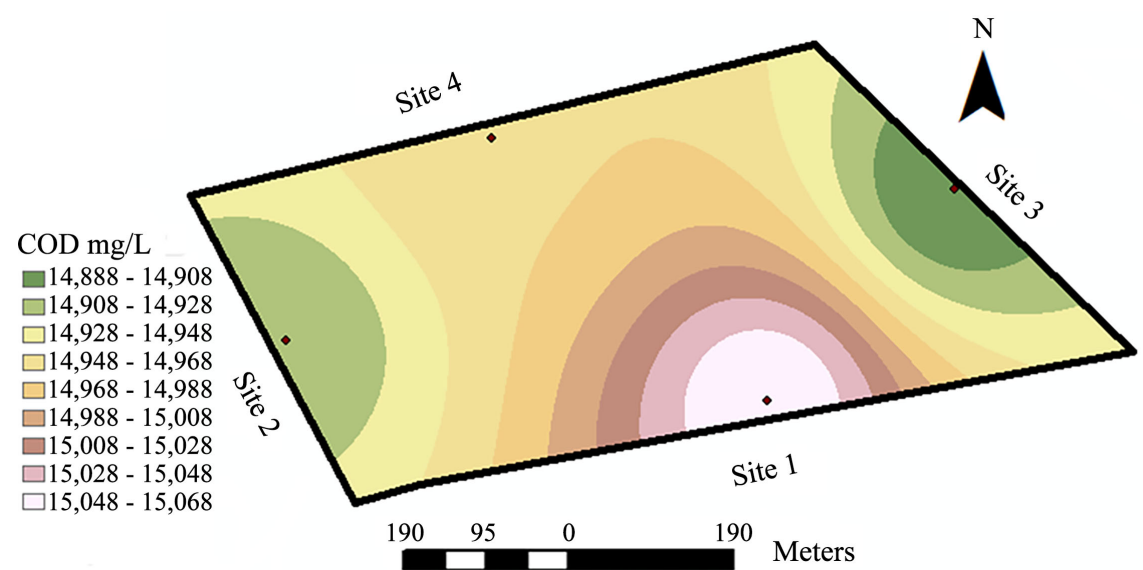

Figure 5. COD distribution according to ArcGIS software in the leachate lagoon.

Table 2. Stages of leachate treatment by Fenton oxidation.

\begin{tabular}{ccccc}
\hline Leachate & Site 1 & Site 2 & Site 3 & Site4 \\
\hline Crude $(\mathrm{mg} / \mathrm{L})$ & $15,069.43 \pm 19.84$ & $14,904.82 \pm 57.72$ & $14,889.48 \pm 29.97$ & $14,912.04 \pm 81.26$ \\
With adjusted $\mathrm{pH}(\mathrm{mg} / \mathrm{L})$ & $11,786.78 \pm 65.72$ & $11,716.55 \pm 77.38$ & $11,889.44 \pm 57.67$ & $11,764.83 \pm 30.55$ \\
Oxidized by Fenton reagent $(\mathrm{mg} / \mathrm{L})$ & $519.23 \pm 15.66$ & $671.35 \pm 25.34$ & $444.12 \pm 30.54$ & $454.53 \pm 38.30$ \\
\hline
\end{tabular}


an oxidation potential of $\mathrm{E}^{\circ}=+0.20 \mathrm{~V}$, thus helping in degrading the humic material. The reduction in COD of leachate per site was on average: for site 1: $3282.65 \mathrm{mg} / \mathrm{L}$, for site 2: $3188.27 \mathrm{mg} / \mathrm{L}$, for site $3: 3000.04 \mathrm{mg} / \mathrm{L}$ and for site 4 : $3147.21 \mathrm{mg} / \mathrm{L}$; If the averaged COD is considered in this lagoon of leachate, there was a reduction of $3154.54 \mathrm{mg} / \mathrm{L}$ which is equivalent to $21.11 \%$.

\subsection{Fenton 0xidation}

The next step was to apply the Fenton reagent. Table 2 shows the results of both sites and points of the leachate lagoon.

A strong decrease in COD was observed, due to the presence of the $\mathrm{HO} \bullet$ and HOO. radicals. By considering average of the lagoon, there was a reduction of $14,421.63 \mathrm{mg} / \mathrm{L}$, from beginning with the crude leachate, which is equivalent to $96.50 \%$.

\subsection{Complementary Oxidation Using an Ozone-UV Combination}

Table 2 shows the residual leachate degradation values from the Fenton treatment, subsequently an oxidation was carried out by a combination of ozone and $\mathrm{UV}\left(\mathrm{O}_{3}+\mathrm{UV}\right)$, producing a strong degradation. At this stage, the degradation kinetic curves were obtained constructing $\mathrm{Ci} / \mathrm{Co}$ graphs $(\mathrm{Ci}$ is the concentration over time and Co is the initial concentration), to obtain the profile of the curve of each run, Figure 6(a). By the shape of the curves, a first order kinetics was observed. That was corroborated when constructing the $\mathrm{Ln} \mathrm{Ci} / \mathrm{Co}$ vs Time curves. Figure 6(b) shows the logarithmic graphs $\mathrm{Ln} \mathrm{Ci} / \mathrm{Co}$ vs time of each run and their constants $\mathrm{K}$, which were very close to each other.

\subsection{Oxidation Treatments Representation and Performance Percentages in Each Stage}

Finally in Figure 7(a) are presented how progressed the degradation of the leachate in each site of the lagoon in each treatment. From the crude leachate, after

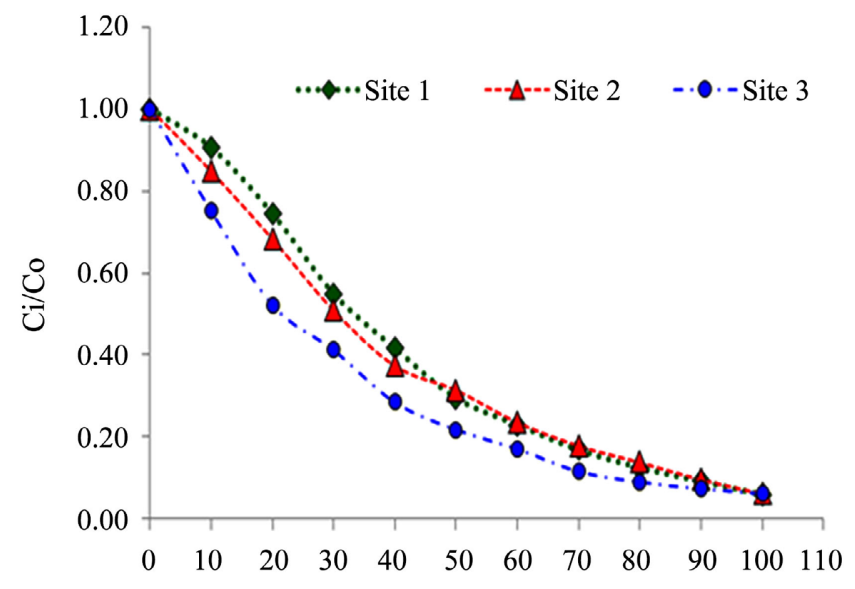

(a)

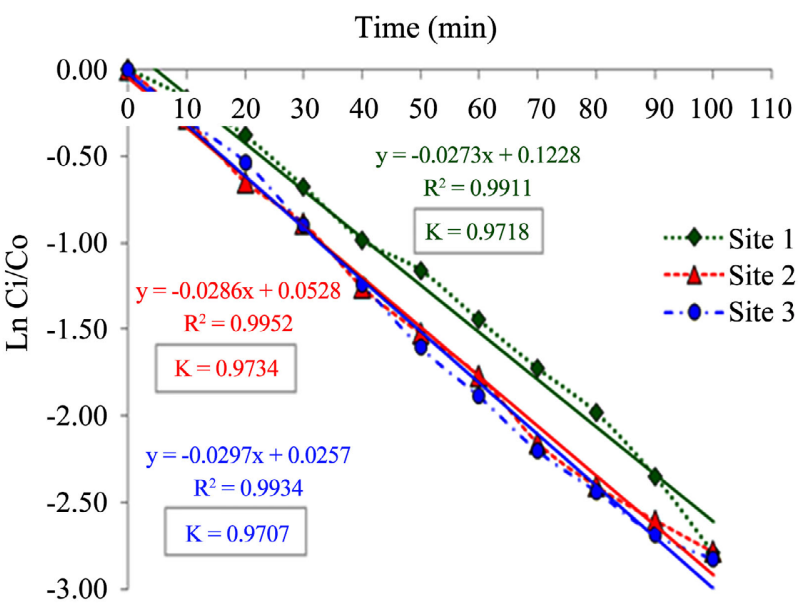

(b)

Figure 6. (a) Kinetics curves profile resulting from ozone-UV oxidation. (b) First order kinetic runs. 


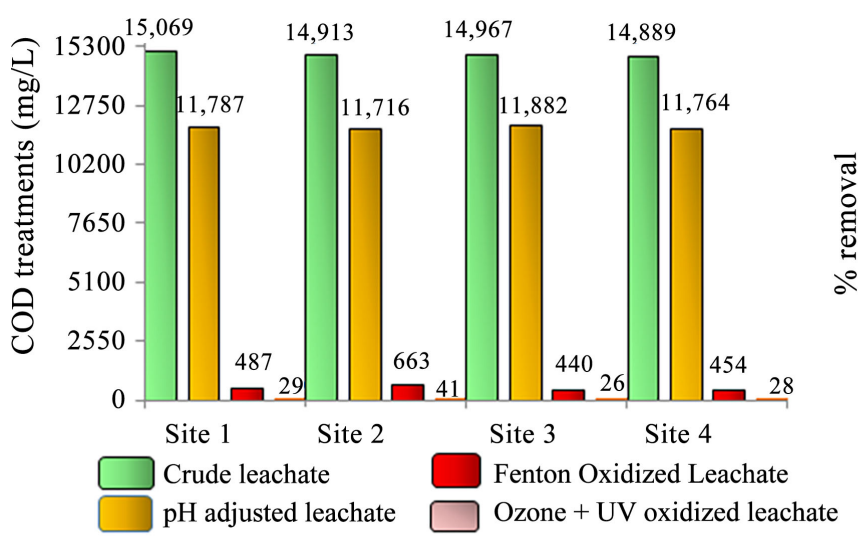

(a)

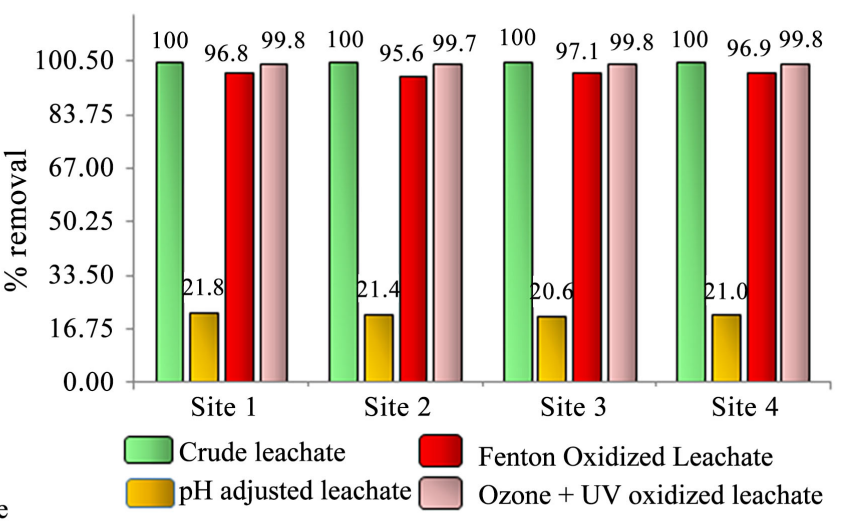

(b)

Figure 7. (a) Treatments stages. (b) COD removal efficiency in each treatment.

$\mathrm{pH}$ adjusted, where concentrated $\mathrm{H}_{2} \mathrm{SO}_{4}$ played an important role, at this stage the oxidation begins. Afterwards the Fenton reaction, which was the strongest and more efficient oxidation, there it was a great decrease in COD and finally with the ozone-UV combination oxidation, almost total degradation was achieved. By analyzing Figure 7(b), the efficiency of each treatment is observed. Considering the combined ozone-UV oxidation treatment, there was a saving of time and the experimental error regarding the handling of the samples was minimized.

\section{Conclusion}

With the Fenton and the Ozone-UV Oxidations of these leachates, an efficiency greater than $96 \%$ was obtained, achieving complete the organic matter degradation. The $\mathrm{pH}$ adjustment was important. By means of the combined oxidation of the Ozone-UV system, the kinetic curves $\mathrm{Ci} / \mathrm{Co}$ vs time presented kinetics of the first order. The kinetic constants resulted of each run with values very close to each other. Performing the Ozone-UV combination in a single step allowed to save experimentation time and avoid experimental errors by handling the samples in less time than if it were done in separate steps.

\section{Conflicts of Interest}

The authors declare no conflicts of interest regarding the publication of this paper.

\section{References}

[1] Méndez, R., Novelo, A., Coronado, V., Castillo, E. and Sauri, M.R. (2008) Removal of Organic Matter and Heavy Metals from Leachates by Dissolved Air Flotation. Ingenieria, Revista Académica, 12, 13-19.

[2] Mendez, R., Medina, E., Quintal, C., Castillo, E. and Sauri, M. (2002) Treatment of Leachates with Activated Carbon. Ingenieria, Revista Académica, 6, 19-27.

[3] Obuli, P. and Kurian, J. (2007) Bioreactor Landfills for Sustainable Solid Waste Management. Proceedings of the International Conference on Sustainable Solid Waste 
Management, Chennai, 466-473. https://www.academia.edu/6535711/BIOREACTOR LANDFILLS FOR SUSTAIN ABLE SOLID WASTE MANAGEMENT

[4] Kiss, K.G. and Encarnación, A.G. (2006) Products and Impacts of the Decomposition of Urban Solid Waste at Final Disposal Sites. INE Ecological Gazette, 79, 39-51.

[5] Tchobanoglous, G., Theisen, H. and Vigil, S.A. (1994) Integral Management of Solid Waste. McGraw Hill, New York.

[6] Wu, C., Chen, W., Gu, Z. and Li, Q. (2021) A Review of the Characteristics of Fenton and Ozonation Systems in Landfill Leachate Treatment. Science of the Total Environment, 762, Article ID: 143131. https://doi.org/10.1016/j.scitotenv.2020.143131

[7] Zamora-Villafranco, E., Barceló-Quintal, I.D, Vega-Paz, A., Solís-Correa, H.E., Méndez-Novelo, R.I. and Giacomán-Vallejos, G. (2016) Leachate Treatment by Fenton Oxidation and Adsorption on Eggshell and Activated Carbon. British Journal of Applied Science \& Technology, 17, 1-18. https://doi.org/10.9734/BJAST/2016/28051

[8] Zamora-Villafranco, E., Barceló-Quintal, I.D., Gomez-Salazar, S., Barceló-Quintal, M., Solís-Correa, H.E. and Soriano-Rodríguez, J.M. (2014) Adsorption Kinetics of Matter Contained in a Leachate Using Eggshell and Active Carbon. Journal of Environmental Protection, 5, 608-619. https://doi.org/10.4236/jep.2014.57062

[9] May-Marrufo, A.A., Méndez-Novelo, R.I., Barceló-Quintal, I.D., Solís-Correa, H.E. and Giacomán-Vallejos, G. (2017) Leachate Treatment by Heterogeneous Fenton on an Activated Carbon Substrate with Fe(II) Impregnated. Journal of Environmental Protection, 8, 524-539. https://doi.org/10.4236/jep.2017.84036

[10] Singh, S.K. and Tang, W.Z. (2013) Statistical Analysis of Optimum Fenton Oxidation Conditions for Landfill Leachate Treatment. Waste Management, 33, 81-88. https://doi.org/10.1016/j.wasman.2012.08.005

[11] Deng, Y. (2007) Physical and Oxidative Removal of Organics during Fenton Treatment of Mature Municipal Landfill Leachate. Journal of Hazardous Materials, 146, 334-340. https://doi.org/10.1016/j.jhazmat.2006.12.026

[12] Barbusinski, K. (2009) Fenton Reaction Controversy Concerning the Chemistry. Ecological Chemistry, 16, 347-358.

[13] Perkowski, J., Jozwiak, W., Kos, L. and Stajszszyk, P. (2006) Application of Fenton's Reagent in Detergented Detergent Separation in Highly Concentrated Water Solutions. Fibres \& Textiles, 14, 114-119.

[14] Solis-Correa, H.E. (2011) Indigo Degradation through Advanced Oxidation Processes. Doctoral Thesis, Autonomous Metropolitan University, Campus Azcapotzalco.

[15] Moradian, F., Ramavandi, B., Jaafarzadeh, N. and Kouhgardi, E. (2020) Effective Treatment of High-Salinity Landfill Leachate Using Ultraviolet/Ultrasonication/Peroxymonosulfate System. Waste Management, 118, 591-599. https://doi.org/10.1016/j.wasman.2020.09.018

[16] Primo, M.O. (2008) Improvements in the Treatment of RSU Landfill Leachate through Advanced Oxidation Processes. Doctoral Thesis, University of Cantabria, Cantabria.

[17] Garcia-Molina, V. (2006) Wet Oxidation Processes for Water Pollution Remediation. Doctoral Thesis, University of Barcelona, Barcelona.

[18] Secretary of Commerce and Industrial Development (1980) NMX-AA-003-1980, Mexican Standard. Wastewater Sampling. 
[19] Secretary of Commerce and Industrial Development (SCFI), Mexican Standard (2013) NMX-AA-007-2013. Water Analysis. Temperature Measurement in Natural Waters, Treated Wastewater. Testing Method.

[20] Secretary of Commerce and Industrial Development (SCFI) (2016) NMX-AA-008SCFI-2016, Mexican Standard. Water Analysis. PH Measurement in Natural, Waste and Treated Wastewater. Testing Method.

[21] Secretary of Commerce and Industrial Development (2018) NMX-AA-093-SCFI2018, Mexican Standard. Water Analysis. Measurement of Electrical Conductivity in Natural, Waste and Treated Wastewater. Testing Method.

[22] ASTM (1996) ASTM D1498-14, Standard Test Method for Oxidation Reduction Potential of Water. ASTM, USA.

[23] Standard Methods (1997) Standard Methods 5520C and 5520D, Standard Methods for the Examination of Water and Wastewater. American Public Health Association, Washington DC.

[24] Zamora-Villafranco, E. (2014) Treatment of a Leachate from a Sanitary Filling through the Processes of Advanced Fenton-Adsorption Oxidation Using Eggshell and Activated Charcoal. Doctoral Thesis, Autonomous Metropolitan University, Campus Azcapotzalco.

[25] Kulikowska, D. and Klimiuk, E. (2008) The Effect of Landfill Age on Municipal Leachate Composition. Bioresource Technology, 99, 5981-5985.

https://doi.org/10.1016/j.biortech.2007.10.015

[26] Dharmarathne, N. and Gunatilake, J. (2013) Leachate Characterization and Surface Groundwater. International Journal of Scientific Research, 3, 1-7. 